\title{
COST OPTIMIZATION IN AGRIBUSINESS BASED ON LIFE CYCLE COSTING
}

\author{
Bojan Savić1, Ivan Milojević2, Vesna Petrović ${ }^{3}$ \\ *Corresponding authorE-mail: bsavic@gmail.com
}

\begin{abstract}
A R T I C LE IN F O
A B S T R A C T

Review Article

In efforts to achieve and sustain competitiveness and

Received: 31 March 2019

contribute to the goal of sustainable development of society,

Accepted: 05 June 2019 entity management requires information that will enable the adoption of adequate decisions. The changed business doi:10.5937/ekoPolj1903823S

UDC 657.15:005.51]:338.43 environment and the growing importance of the issues that emerge from the domain of traditional business, both spatial and temporal, have necessitated the monitoring of costs

Keywords:

cost optimization, life cycle costing, competitiveness, sustainable development, agribusiness. not only during the production phase, but throughout the entire grain cycle of the product. Since conventional cost accounting systems do not have the capacity to generate the above information, in theory and practice, a life cycle costing system (LCC) has been developed. The aim of the paper is to point out the specificity and importance of JEL: M41, Q51 perceiving and capturing the impacts and consequential costs that arise during the life cycle of the product, with particular reference to agribusiness, precisely because of the complexity of optimizing costs in that sector.
\end{abstract}

(C) 2019 EA. All rights reserved.

\section{Introduction}

The business world is exposed to accelerated changes, followed by the emergence of numerous complex challenges, increasingly rigorous legislation and various stakeholder pressures. In such conditions, management should ensure not only the survival and development of the entities, but also to contribute to the sustainable development of a wider society through the business of the company. Regarding agriculture and the accompanying processing industry, accountability is even greater, given that, although they have an important role to play in ensuring food security of society, these sectors simultaneously represent an important source of emissions that degrades the environment and impairs quality of life.

1 Bojan Savić, Ph.D., assistant professor, University of Belgrade, Agriculture faculty, Nemanjina street No. 6, Zemun, +381 114413 211, bsavic@gmail.com

2 Ivan Milojević, Ph.D., full professor, University of Defence, Military Academy, Public finance Department, Pavla Jurišića Šturma No. 33, +381690702697, drimilojevic@gmail. com, ORCID ID: https://orcid.org/0000-0003-3653-3477

3 Vesna S. Petrovic PhD, Assistant professor, Faculty of Economics and Finance, University Union-Nikola Tesla, 11000 Beograd, Cara Dusana 62-64,+381607170071, al.petrovicpn@ gmail.com, ORCID ID: https://orcid.org/0000-0001-5476-8371

http://ea.bg.ac.rs 
In order to succeed in this effort, it is necessary for the management to have adequate information on the impact of agricultural and food products throughout the life cycle. One of the important sources of information for decision-making is cost accounting. Since the information generated by conventional costing systems is an adequate response in circumstances where business conditions were far simpler, there was a need to calculate costs that would allow monitoring of value flows in a much more complex economic environment. As a result of the effort to provide relevant information, a whole range of advanced cost accounting systems have been developed that provide monitoring capability and some additional aspects of the business, not just flows of internally generated values, which at the same time provide the information necessary to prepare strategic responses to a number of contemporary challenges.

The paper will point out the specifics and importance of calculating costs by product life cycle phases, with a special emphasis on the challenges of cost optimization in the agribusiness sector.

\section{Objectives of Life cycle costing}

Although the first cost-of-living ideas in product life cycle phases appeared a little over half a century ago, the more intense application of the concept began three and a half decades ago in the United States. Namely, during the given period LCC had a binding character in the planning, design and construction of buildings, as well as various infrastructure projects. Over time, this system of calculation and cost management has found its application not only in other industries, but also in the public sector.

The basic idea of a life cycle costing (LCC) is to capture all the costs that arise from the creation of an idea, through the development of products, its production, and post-sales services, up to the withdrawal of the product from use. As such, the concept should provide a picture of overall costs over the life of a product, which is at the same time the starting point for assessing the viability of the product being monitored. While traditional cost accounting systems primarily focus on the production and sales phase, cost accounting by product life cycle stages includes and monitors costs incurred in the market research phase, design and product development during the manufacturing process, quality control, storage, distribution, handling, disposal and environmental protection. In other words, this system of calculation of costs generates information generated in the pre-production, production and post-production phase of the life cycle of the product (Iannone et al., 2016).

Basically, the decision to apply the LCC has many factors, and some of them are the following: the necessity to accurately identify cost drivers, support for strategic decision-making, product design improvement, the perception of the effects of applying new technology in the entity, budget projections for the future periods. In other words, the primary goal of applying this costing system is to provide information that will contribute to the realization of the goal of optimizing costs. Cost optimization is a very delicate task whose importance is particularly evident in terms of intensifying 
competition, a significant increase in costs incurred in the product maintenance and disposal phase, due to violations of environmental regulations and the payment of various penalties and other (Dhillon, 1989).

Various variants of the LCC have been developed over time, ranging from the basic version which examines economic performance to the more advanced, which includes and considers the costs of social and environmental impact of the product.

Conventional LCC is most commonly used, as it has been successfully implemented for many years and as such focuses on the economic evaluation of the effects of resource use through individual phases of the life cycle, including the costs associated with the product, borne directly by one participants in the product value chain - manufacturer, distributor or user of the product (Vladisavljević \& Vukasović, 2017). This variant of cost accounting often neglects the need to internalize external costs or costs that are not directly noticeable or not directly borne by one of the above-mentioned participants. In other words, this type of cost accounting significantly narrows down the concept of product life cycle, and therefore does not include all the costs that can actually arise during certain product life cycle phases. Conventional variant LCC includes costs incurred in the pre-production and production phase, then the costs of exploitation of products (related consumption of materials or energy), maintenance costs, costs of withdrawing products from use, disassembly and disposal (SIGMA, 2016).

An advanced variant of LCC refers to the inclusion of costs arising from degradation of the environment, that is the negative environmental effects of the product. These are external costs that are expected to have an internal character in the short term. The environmental approach to cost accounting can be used as a planning tool, but also in accounting for reporting purposes. The concept is often used for the purpose of evaluating and selecting alternatives in the product design phase, since precisely this phase predominantly defines future emissions, and therefore costs during product lifecycle (UNEP, 2009).

For cost-benefit analysis and cost control that is related to a particular product, it is necessary to extend the concept of life cycle to include a wider set of costs, respecting those costs, which not only directly but indirectly (through externalities or impacts on the wider environment) are tangling with stakeholders. It is a LCC that examines the social aspects of a particular product, or involves the effects of its production and use on a wider society (social well-being, job security, etc.). Accordingly, the management of the company is to recognize the social hotspot, or a problem that can contribute to the improvement of social conditions and social well-being (Prasara \& Gheewala, 2018). For the purpose of determining the cost, this approach provides for the application of the company's time preference rate to be used when discounting the projected amount of costs (it is usually the application of an approximate value that is lower than $0.1 \%$ on an annual basis), but other approaches can be used (Lichtenvort et al., 2008).

One of the key specifics of the LCC is reflected in the requirement to include the concept of the time value of money while including and accounting for costs that will only arise 
in the post-production phase, since these costs only arise after a few years when it comes to capital goods. This aims to ensure the comparability of individual amounts of costs, regardless of the stage in which the life cycle phases have occurred. Hence, the costs are to be expressed by monetary units of the same purchasing power, which means that the projected costs with the financial mathematics apparatus are reduced to the present value. These costs are expected, they will only occur in the future, more precisely in the period when the product is located with the buyer (user) and as such, these costs primarily encompass the monetary effects of the negative impact of the product on the environment and other stakeholders, then the maintenance activities (servicing) product and its withdrawal from use, after which the issue of the costs of disposal of products should be solved in an environmentally friendly way (Dhillon, 1989; Chessell, 2018).

From the previous it follows that the application of the LCC requires first to estimate the value of future costs, and then to determine the appropriate discount rate, in order to reduce the projected size to the present value. Costing assumes that it starts from known types and amounts of costs (historical data derived from normal business), then models based on expected performance using the professional judgment of accountants and other experts, considering the best assumptions regarding future technological and market trends (Bennett \& Ferry, 1987).

According to the rule, the minimum discount rate must be at least equal to the average market interest rate corrected for the expected inflation rate, and for those needs can be used the weighted average cost of capital or the internal rate return method is applied during an investment decision process in an enterprise. The decision on choosing the discount rate is left to the management accountant.

The previous indicates that LCC can contribute to the sustainable development of businesses and society through the generation of information that will enable the identification of technologies, products and services that are economically, socially and environmentally friendly. In the continuation of the paper, the specifics of capturing the effects and estimating the associated costs through individual phases of the life cycle of the product will be considered.

\section{Methods and Materials}

The starting point for the successful implementation of the LCC is the assessment of the product's impact during its lifecycle (LCA). It is a technique that tends to identify, quantify and categorize the various potential environmental effects that occur at each stage of the product's lifecycle. This implies that the functional units that will be monitored are carefully defined, since different observation units result in different results. One of the elements to be considered when defining a functional unit in agribusiness is the yield and weight of the product. The key constraint of this approach is that in certain production lines such a defined functional unit does not fully reflect the complex effects of products and processes on the environment, which makes it possible to combine 
more functional units (Cerutti et al., 2014), then the area of land used, product quality - organoleptic properties, nutritional composition, and others (Notarnicola et al., 2012).

What is specific to the mentioned concept of impact assessment, which through the company's products produces, is that the concept of the life cycle is not observed through a time dimension, as is the case with LCC, but the life cycle is viewed in the context of the physical chain of material flows that are related to the product, which arise from the phase of material acquisition, through production, to waste management (Gluch \& Baumann, 2004).

According to Gunady et al. (2012) in the case of agricultural production it is possible to include the following phases and associated activities: pre-farm (extraction, processing, manufacturing, transportation to farm), on-farm (N-Fertiliser use, irrigation, on-farm transport), post-farm (storage, packaging, transportation to distribution centre and to grocer). The effect emanates from the emission depends on the amount and the properties of the emitted substance, the emission characteristics and the environment in which the emission is released (Finnveden et al., 2009).

Life-cycle impact analysis aims to enable (Davis Langdon Management Consulting, 2006):

- Identifying opportunities for improving product / service during its lifecycle;

- Making decisions in industrial, governmental and non-governmental organizations;

- Selecting relevant indicators of environmental performance and adequate measurement techniques;

- Implementation of the eco-labeling scheme of products and the eco-declaration of products as elements of sales promotion.

It is important to note that LCC is not a goal for itself. Namely, it is a part of a broader concept - the product life cycle management that tends to support the investment decision-making process through the design of costs that arise in the long run (Boussabaine \& Kirkham, 2004), or through the efforts of continuous improvement to minimize negative environmental and socio-economic impacts (Reddy et al., 2015). In that sense, the stated costing system generates relevant information by supporting alternative decision-making, among other things for the needs of designing and optimizing product assortment, selecting production technology, and more.

Implementation of the life-cycle impact assessment concept according to the standards of the International Organization for Standardization (ISO 14040-14044) includes four stages (United Nations Environment Program, 2009):

- Determining the goal and scope of the research, defining a functional unit, modeling the approach to be applied;

- Life cycle inventory analysis refers to identifying where the products of the observed system are located, examining processes that lead to the creation of a product, a description of the flows that the company exchanges with the environment, 
including the inputs directly from the nature (raw materials, land) and outputs that emerge in the form of emissions into air, water and land, the use of materials and energy. The amount of elementary flows exchanged is designated as a functional unit. At this stage, data for all processes defined in the model are collected and an adequate calculation is performed;

- Determining the size and significance of the impact associated with the Impact Assessment The social and environmental impact assessment is always carried out at the functional unit level (defined as a measure of the functioning of the system and used for the purpose of comparing and evaluating two or more systems);

- Interpretation of the obtained results of previous phases with defined objectives in order to make appropriate conclusions about the resulting environmental impact and accordingly make certain recommendations.

Once the environmental impacts are quantified, it is possible to approach the cost estimate. Costing techniques can be divided into two groups - qualitative (identifying similarities between products and suitable for use when considering a limited time frame - pre-judgment based on previous cases) and quantitative techniques that are much more precise and can be applied to different products for the needs costing throughout the whole life cycle. In practice, moving costs is often not linear, and the use of a larger amount of resources does not inevitably lead to a proportional increase in the output achieved. In addition to inventory analysis, sensitivity analysis is used to assess the environmental impacts. In this regard, the effects of replacing inputs, materials and sources of energy with negative environmental implications are examined (De Marco et al., 2018), or the effects of resource recycling on environmental performance (Song et al., 2013). On the other hand, the sensitivity analysis is used to examine the cost dynamics and other economic performances of the observed product, for example, based on the change in the applied discount rate (Rodger et al., 2018).

\section{Results and Discussion}

Cost optimization involves taking effort to reduce the value of the target function. The goal in this case is to achieve cost leadership. In doing so, it is necessary to take into account that the cost-reduction efforts do not impair the quality and functionality of the products, since they are important elements of product competitiveness and market share. The circumstance that at the same time it is necessary to achieve more goals - cost leadership and the corresponding product quality with a minimum ecological footprint, finding the optimal solution can be based on a multi-criteria analysis of the decision. This process involves identifying problems (decisionmaking context, identifying key stakeholders and their interests), structuring problems and developing alternatives and criteria for their assessment, evaluating performance and ranking alternatives by respecting each of the defined criteria, carrying out the key stakeholder values and decision makers, synthesis results, as well as an analysis of the sensitivity of the results on the changes in parameters in the models (Saarikoski et al, 2016). In the literature, the optimal solution is considered to be the solution that is maximally good or minimal bad. 
LCC contributes to solving the problem of optimization, i.e. achieving a minimum function of cost function, primarily through identifying and comprehensively displaying the corpus of costs that can arise during the life cycle of a product. After that, the management of the company is to perform a strategic cost analysis and undertake activities towards their reduction to the optimal amount. One significant part of the total costs in conventional costing systems remains invisible, denying relevant information to decision makers. Thus, for example, conventional costing systems include direct costs such as material and work costs, as well as indirect costs allocated by appropriate keys. However, contingent costs related to environmental sanctions and penalties, costs arising from claims for injuries at work, environmental degradation, staff training, installation and maintenance of pollution measurement systems etc. become apparent only in the conditions of application of the LCC (Vlachy, 2014). Traditional cost accounting systems underwater the costs under the category of general costs.

Agriculture and related process industries undoubtedly have a significant impact on the environment and society and are often seen as a significant factor of environmental degradation, through greenhouse gas emissions and other pollution that, among other things, lead to climate change (Praća et al., 2017). Natural resources, especially land and water resources, play a key role in agricultural production. In order to ensure production efficiency, it is necessary to look at the effects of land, water and energy use. This is especially due to the fact that many resources for agriculture are currently being used in an unsustainable way. Impact analysis through the prism of the life cycle can be viewed at the level of the whole branch when observing the average ecological performance in the production of particular goods, for example, in one region or country, or at the micro level, when the subject of observation is the impact of a specific product or production technology at the level the observed company. It is about the impacts of the production and use / consumption of products on society and the environment - climate change, availability of drinking water, changes in soil quality, the impact of toxic substances on human health, the exhaustion of non-renewable resources, and others (Dusmanescu et al., 2014; Bjorn et al., 2018).

From the perspective of the concept of product life cycle, it is possible to identify six stages through which food products, as key agricultural products, have an impact on the immediate and wider environment: the production and transport of inputs to the farm, cultivation, processing, distribution, consumption and waste management. It is necessary to point out that the greatest impact is achieved in the initial stages, when the construction of accommodation capacities, the production of agro-technology and equipment, the preparation of land, the cultivation of animals and plant crops, the use of fertilizers and pesticides, the consumption of water, fuel and other are carried out. The processing involves the conversion of inputs produced on the farm into final food products. Distribution refers to transport before and after processing. In the consumption phase, environmental impacts are also reflected in the accompanying packaging, storage, food preparation and waste occurrence. Finally, waste management can be carried out using a variety of technologies - lazing in the land, incineration, compost production, and other methods (Dijkman et al., 2018). 
The guiding principles for determining the environmental impact of food products (food and beverages) defined by the European Food SCP Round Table (2013) include: identifying and analyzing environmental impacts throughout the life cycle, identifying a significant potential life-cycle impact, application of scientific methodology, periodic review and review of environmental impacts in the supply chain, informing in a comprehensible and comparable way, a clear understanding of the framework and importance of environmental information, ensuring transparency of information, applied methodologies and assumptions used, support for innovations, environmental protection and consumer awareness.

In the continuation, for the production and processing of raspberries, the implementation of the life cycle concept will be presented for the purposes of identifying potential environmental impacts and thus the costs that arise, through the stages defined by ISO that were previously shown in the paper. Because of its biological properties, berries are not persistent and calibrate quickly, which requires them to be frozen or processed as soon as possible in products with a higher degree of added value. In addition, manufacturers may consider whether to offer a conventional cultivated or organic raspberry to the market. Each of the above alternatives carries with it certain influences on the environment, and therefore costs and benefits.

Objective and framework of the research - Evaluation of the ecological, social and economic impacts of the two products - products made from conventional raspberries and products for which the raspberries used are produced by respecting the principles of organic production. The functional unit can be defined per kilogram of fresh raspberries used, which provides an opportunity to look at and compare the ecological impact of raspberries produced at different locations. The results can be expressed per hectare of land surfaces to see the effects of the applied preparations in a particular region.

Analysis of input and output flows that are the subject of exchange with the environment include the production of preparations and equipment used in the preparation of soil for raspberry cultivation, purchase of seedlings, procurement of necessary equipment, transport means, use of pesticides and inorganic fertilizers, construction of production and storage capacities, procurement of sugar and alternative sweeteners, packaging production, water consumption, electricity, fossil fuel during work and transport, waste disposal, and others (Tamburini et al., 2015).

Identifying the impact on the environment of each of the observed products: Organically produced raspberries require the exploitation of a larger area of land, as lower yields are achieved than conventional production. Lower raspberry yield in organic production requires the cultivation and exploitation of a large number of seedlings, which further leads to increased emissions and intensification of climate change. On the other hand, the conventional product leads to contamination of soil and waterways.

Identifying the impact on the environment of each of the observed products: Organically produced raspberries require the exploitation of a larger area of land, since lower yields relative to conventional production are achieved. Lower raspberry yield in organic 
production requires the cultivation and exploitation of a large number of seedlings, which further leads to increased emissions and intensification of climate change. On the other hand, the conventional product leads to contamination of soil and waterways.

When analyzing costs arising from various activities that the company applies in the production process, it is necessary to identify the key cost drivers, to make efforts to reduce the amount of costs incurred and, based on that, make decisions about the type and extent of production in the coming periods. In addition to the expenditure component, it is necessary to also look at uses or incremental incomes that can be achieved by choosing an environmentally friendly alternative. These are revenues that can be realized on the basis of ecological premium, building company reputation, increasing market share, customer loyalty, and more. In order to achieve comparability, on the costs and revenues that will arise in future periods, it is necessary to apply the appropriate discount rate in order to determine their present value. Cost optimization through the prism of the concept of product life cycle in agribusiness entities should contribute to finding economically, socially and environmentally acceptable solutions for the production recipe, packaging and transport of food products (Notarnicola et al., 2017).

The circumstance that potential impacts are observed at company level, but also from the perspective of all supply chains, it is necessary to determine the costs and benefits that will arise for individual participants in the product value chain as well as key stakeholders. On the basis of cost-benefit analysis, management will identify alternatives where the most cost-benefit ratio is the most favorable.

\section{Conclusion}

Cost accounting as an important source of information should support management decision-making in order to ensure competitiveness of the entities and enable corporate and socially sustainable development. This challenge can very successfully respond to the calculation of costs by product life cycle phases. The purpose of the stated costing system is to enable the optimization of total operating costs, which is achieved by capturing and monitoring additional categories of costs that are not the subject of consideration in conventional cost accounting systems. In other words, this means that it also includes some additional aspects of business that have strategic significance for agribusiness entities, such as the impact of products and processes on the wider society, the environment and related climate change. This costing system represents the segment of a broader concept - Life cycle management, which seeks to support the decision-making process and through efforts to achieve continuous improvements in the production process, contributing to the minimization of negative environmental and socio-economic impacts, and thus the overall cost of doing business. In this regard, LCC provides significant information support in alternative business decision-making and efforts to achieve sustainable development of enterprises and society. 


\section{Ackonowledgements}

The paper is a result of the researching project No. III-46001 «Development and application of new technologies in production of competitive food value-added products for domestic and foreign markets - Let's make wealth from the wealth of Serbia".

\section{Conflict of interests}

The authors declare no conflict of interest.

\section{References}

1. Bennett J., \& Ferry D. (1987). Towards a simulated model of the total construction process. Building Cost Modeling and Computers, London, E \& FN Spon.

2. Bjorn A., Owsianiak M., Molin C., \& Laurent A. (2018). Main Characteristics of LCA, in: Life Cycle Assessment - Theory and Practice, eds. Hauschild M., Rosenbaum R., Olsen S., Springer International Publishing.

3. Boussabaine H., \& Kirkham R. (2004). Whole Life-Cycle Costing, Risk and Risk Responses, Blackwell Publishing Ltd.

4. Cerutti, A.K., Beccaro, G.L., Bruun, S., Bosco, S., Donno, D., Notarnicola, B., \& Bounous, G. (2014). Life cycle assessment application in the fruit sector: State of the art and recommendations for environmetal declarations of fruit products, Journal of Cleaner Production, 73, 125-135.

5. Chessell, D. (2018). The Jobless Economy in a Post-Work Society: How Automation Will Transform the Labor Market. Psychosociological Issues in Human Resource Management, 6(2), 74-79.

6. Davis Langdon Management Consulting, (2006). Literature review of life cycle costing (LCC) and life cycle assessment (LCA), Draft review, Retrieved from https://www.tmb.org.tr/arastirma_yayinlar/LCC_Literature_Review_Report.pdf (October 12, 2018).

7. De Marco, I., Riemma, S., \& Iannone, R. (2018). Uncertainty of input parameters and sensitivity analysis in life cycle assessment: An Italian processed tomato product, Journal of Cleaner Production, 177, 315-325.

8. Dijkman T., Basset-Mens C., Anton A., \& Nunez M. (2018). LCA of Food and Agriculture, in: Life Cycle Assessment - Theory and Practice, eds. Hauschild M., Rosenbaum R., Olsen S., Springer International Publishing.

9. Dhillon B. (1989). Life Cycle Costing, Gordon and Breach Science Publishers.

10. Dusmanescu, D., Andrei, J., \& Subic, J. (2014). Scenario for implementation of renewable energy sources in Romania. Procedia Economics and Finance, 8, 300-305.

11. European Food SCP Round Table, (2013). Envifood Protocol Environmental Assessment of Food and Drink Protocol, Retrieved from http://www.food-scp.eu/ files/ENVIFOOD_Protocol_Vers_1.0.pdf(October 19, 2018). 
12. Finnveden, G., Hauschild, M.Z., Ekvall, T., Guinee, J., Heijungs, R., Hellweg, S., Koehler, A., Pennington, D., \& Suh, S. (2009). Recent developments in Life Cycle Assessment, Journal of Environmental Management, 91, 1-21.

13. Gluch, P., \& Baumann, H. (2004). The Life Cycle Costing Approach: A Conceptual discussion of the usefulness for environmental decision-making, Building and the Environment, 39(5), 571-580.

14. Gunady, M.G.A., Biswas, W., Solah, V.A., \& James, A.P. (2012). Evaluating the global warming potential of the fresh produce supply chain for strawberries, romaine/cos lettuces (Lactuca sativa), and button mushrooms (Agaricus bisporus) in Western Australia using life cycle assessment (LCA), Journal of Cleaner Production, 26, 81-87.

15. Iannone, R., Miranda, S., Riemma, S., \& De Marco, I. (2016). Improving environmental performance in wine production by a life cycle assessment analysis, Journal of Cleaner Production, 111, 172-180.

16. Lichtenvort K., Rebitzer G., Huppes G., Ciroth A., Seuring S., Schmidt W., Ganther E., Hoppe H., Swarr T., \& Hunkeler D. (2008). Histrory of Life Cycle Costing, its Categorization, and its Basic Framework, in: Environmental Life Cycle Costing, eds. Hunkeler D., Lichtenvort K., Rebitzer G., SETAC Press.

17. Notarnicola, B., Tassielli, G., \& Renzulli, P. (2012). Modeling the Agri-food Industry with Life Cycle Assessment, in: Life cycle assessment handbook: A guide for environmentally sustainable product, ed. Curran, M., A., John Wiley \& Sins, Inc., New Jersey.

18. Notarnicola, B., Sala, S., Anton, A., McLaren, S., Saouter, E., \& Sonesson, L. (2017). The role of life cycle assessment in supporting sustainable agri-food systems: A review of the challenges, Journal of Cleaner Production, 140, 399-409.

19. Prasara, J., \& Gheewala, S. (2018). Applying Social Life Cycle in the Thain Sugar Industry: Challenges from the field, Journal of Cleaner Production, 172, 335-346.

20. Praća, N., Paspalj, M., \& Paspalj, D. (2017). Impact of modern agriculture to sustainable development of guidelines, Oditor- časopis za menadžment, finansije i pravo, Centar za ekonomska i finansijska istraživanja, Beograd, 3(1), 37-51. [In Serbian: Праћа, Н., Паспаљ, М., \& Паспаљ, Д. (2017). Економска анализа утицаја савремене пољопривреде на одрживи развој].

21. Reddy, R., Kurian, M., \& Ardakanian, R. (2015). Life-cycle Cost Approach for Management of Environmental Resources, Springer.

22. Rodger, J-M., Kjaer, L., \& Pagoropoulos A. (2018). Life Cycle Costing: An Introduction, in: Life Cycle Assessment - Theory and Practice, eds. Hauschild M., Rosenbaum R., Olsen S., Springer International Publishing.

23. SIGMA, Life Cycle Costing, (2016). Retrieved from http:/www.sigmaweb.org/ publications/Public-Procurement-Policy-Brief-34-200117.pdf (November 10, 2018). 
24. Saarikoski, H., Mustajoki, J., Barton, D., Geneletti, D., Langemeyer, J., GomezBaggethun, E., Marttunen, M., Antunes, P., Keune, H., \& Santos, R. (2016). MultiCriteria Analysis and Cost-Benefit Analysis: Comparing alternative framework for integrated valuation of ecosystem services, Ecosystem Services, 22, 238-249.

25. Song, Q., Wang, Z., \& Li, J. (2013). Envronmental performance of municipal solid waste strategies on LCA method: a case study of Macau, Journal of Cleaner Production, 57, 92-100.

26. Tamburini, E., Pedrini, P., Marchetti, M.G., Fano, E.A., \& Castaldelli, G. (2015). Life Cycle Based Evaluation of Environmental and Economic Impacts of Agriculture Productions in the Mediterranean Area, Sustainability, 7, 2915-2935.

27. United Nations Environment Programme, Guidelines for Social Life Cycle Assessment of Products, 2009, Retrieved from http:/www.unep.fr/shared/ publications/pdf/dtix1164xpa-guidelines_slca.pdf(December 19, 2018).

28. Vlachy, J. (2014). Using Life Cycle Costing for Product Management, Management, Faculty of organizational sciences, Belgrade, 19, 205-218.

29. Vladisavljević, V., \& Vukasović, B. (2017). Contemporary costing systems, Oditor - časopis za menadžment, finansije i pravo, Centar za ekonomska i finansijska istraživanja, Beograd, 3(3), 133-151. [In Serbian: Владисављевић, В., \& Вукасовић, Б. (2017). Савремени системи обрачуна трошкова]. 